\title{
Effect of feeding ensiled maize grain on rumen development and calf rearing performance
}

\author{
E. Sosin-Bzducha ${ }^{1}$, J. Strzetelski ${ }^{2,6}$, F. Borowiec ${ }^{3}$, J. Kowalczyk ${ }^{4}$ \\ and K. Okoń ${ }^{5}$
}

\author{
National Research Institute of Animal Production, \\ ${ }^{1}$ Department of Genetic Resources Conservation, \\ ${ }^{2}$ Department of Animal Nutrition and Feed Science \\ 32-083 Balice, Poland \\ ${ }^{3}$ University of Agriculture in Kraków, Department of Animal Nutrition \\ al. Mickiewicza 24/28, 30-059 Kraków, Poland \\ ${ }^{4}$ The Kielanowski Institute of Animal Physiology and Nutrition, Polish Academy of Sciences \\ 05-110 Jabtonna, Poland \\ ${ }^{5}$ Jagiellonian University, Collegium Medicum, Department of Pathomorphology \\ Grzegórzewska 12, 31-531 Krakow, Poland
}

(Received 19 February 2010; accepted 7 May 2010)

\begin{abstract}
The aim of the study was to determine the effect of replacing barley grain or dry maize ( $50 \%$ by weight) in feed mixtures for calves with ensiled high-moisture maize grain on ruminal and postruminal digestibility of starch, rumen development parameters and rearing performance of calves. The experiment was carried out with 40 bull calves aged between $10 \pm 3$ and 90 days divided into 4 groups of 10 animals per group. The main source of dietary starch was barley in the control group (B), dry maize grain in group $\mathrm{M}_{\mathrm{D}}, 50 \%$ barley and $50 \%$ ensiled maize grain in group $\mathrm{BM}_{\mathrm{S}}$, and $50 \%$ dry maize grain and $50 \%$ ensiled maize grain in group $\mathrm{M}_{\mathrm{D}} \mathrm{M}_{\mathrm{S}}$. The results obtained show that rolled ensiled maize grain can be successfully used in diets for calves reared from 10 to 90 days of age to replace ( $50 \%$ by weight) dry rolled barley or maize grain. However, slightly better production results were obtained when feeding a barley and ensiled maize grain diet, which is probably due to the better intestinal digestibility of protein and starch, as shown by higher intestinal digestibility coefficients of protein and starch as well as lower faecal starch losses. The addition of ensiled maize grain to the diets did not cause significant changes in rumen fermentation, although there was a slight increase in total VFA concentration and proportion of butyric acid, a reduction in $\mathrm{pH}$ of rumen fluid, and calves tended to have higher serum
\end{abstract}

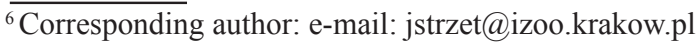


$\beta$-hydroxybutyric acid concentrations at 10 and 12 weeks of age. The replacement of dry grains with ensiled maize grain in the diets for calves did not have an unambiguously favourable effect on rumen papillae development while improving wall thickness of the ventral ruminal sac.

KEY WORDS: calf, starch, performance, rumen development

\section{INTRODUCTION}

The use of different sources of carbohydrates (Suarez et al., 2006a,b) and starch (Khan et al., 2008) in feed mixtures has different effects on the development of metabolic and absorptive functions of the rumen as well as calf rearing performance. Barley, oats and wheat are almost completely digested in the rumen, while ruminal degradation of dry maize grain is slower with much more starch passing to the small intestine (Huntington, 1997). Lesmeister and Heinrichs (2004) showed that different physical processing of dry maize grain may have different effects on rumen development and calf productivity. Compared to dry grain, high-moisture maize grain subjected to ensiling is more rapidly fermented in the rumen to volatile fatty acids (VFA), with smaller amounts of this grain reaching the small intestine, where it is better digested than dry grain, and less undigested starch passes to the large intestine, which may be associated with the lower faecal starch losses (Archibeque et al., 2006).

According to Knowlton et al. (2000), the energy value of ensiled maize grain $(70 \% \mathrm{DM})$ is about $15 \%$ greater than the energy value of dry grain $(>85 \% \mathrm{DM})$. The use of ensiled rather than dry maize grain may not only be more effective in stimulating rumen development through increased VFA production, but also increase starch digestibility in the small intestine by providing more glucose, which is the main source of energy in newborn calves with undeveloped rumen papillae. VFA, especially butyric and propionic acids, are considered to stimulate the development of the absorptive surface of ruminal mucosa. After being absorbed by ruminal epithelium, these acids are metabolized in cell mitochondria to ketoacids which serve as a source of energy for liver synthesis of different substrates (Beharka et al., 1998). Serum concentration of $\beta$-hydroxybutyric acid (BHBA) is a usually accepted indicator of rumen metabolic development (Quigley et al., 1991).

The aim of the study was to determine the effect of replacing barley grain or dry maize ( $50 \%$ by weight) in feed mixtures for calves with ensiled high-moisture maize grain on ruminal and postruminal digestibility of starch, some rumen development parameters and rearing performance of calves. 


\section{MATERIAL AND METHODS}

\section{Experimental design, animal feeding and management}

The experiment was carried out with 40 Polish Holstein-Friesian bull calves aged between $10 \pm 3$ and 90 days which were divided on the analogue principle to 4 equal groups. The main source of dietary starch in the control group (B) was barley, dry maize grain in group $M_{D}, 50 \%$ barley and $50 \%$ ensiled maize grain in group $\mathrm{BM}_{\mathrm{S}}$, and $50 \%$ dry maize grain and $50 \%$ ensiled maize grain in group $\mathrm{M}_{\mathrm{D}} \mathrm{M}_{\mathrm{S}}$ (Table 1). Grains in the mixtures were given in rolled form. In addition,

Table 1. Concentrate composition, as fed, \%

\begin{tabular}{|c|c|c|c|c|}
\hline \multirow{2}{*}{ Ingredient } & \multicolumn{4}{|c|}{ Groups } \\
\hline & $\mathrm{B}$ & $M_{D}$ & $\mathrm{BM}_{\mathrm{s}}$ & $\mathrm{M}_{\mathrm{D}} \mathrm{M}_{\mathrm{s}}$ \\
\hline Barley & 57 & - & 28.5 & - \\
\hline Maize grain, dry & - & 56 & - & 28.5 \\
\hline Maize grain, silage & - & - & 28.5 & 28.5 \\
\hline Oats & 18 & 18 & 19 & 18 \\
\hline Soyabean meal & 21 & 22 & 20 & 21 \\
\hline Premix CJ Komplet ${ }^{1}$ & 3 & 3 & 3 & 3 \\
\hline Limestone & 1 & 1 & 1 & 1 \\
\hline
\end{tabular}

each mixture contained similar amounts of oats, soyabean meal (SBM) and mineral components. Because the mixture that only contained ensiled maize grain as the main source of starch did not match other mixtures for PDI level, it was not included into the experiment. Calves were given colostrum and whole milk before the experiment, and milk replacer from the beginning of the experiment to 56 days of age. Liquid feed, which was prepared from powdered milk replacer, contained (according to manufacturer specification) sweet dried whey, soya protein concentrate, refined vegetable and animal oils, vitamins and probiotics. The concentration of solid milk replacer in liquid feed was $167 \mathrm{~g}$ per litre, which corresponded to a crude protein and fat content of approximately $3.3 \%$ each. Calves were fed individually on ad libitum feed mixtures. Mixtures with ensiled maize grain (groups $B M_{S}$ and $M_{D} M_{S}$ ) were prepared directly before feeding by mixing ensiled maize grain and a supplementary mixture (prepared separately in a feed mixing plant) containing dry grain, SBM and minerals (1:2.5). Different batches of the mixtures were prepared for 1 month and feed intake and refusals were recorded daily. The calves were fed milk replacer solution according to IZ-INRA(2001) recommendations formulating the protein and energy value of feeds, and proportion of ingredients in concentrates using INRAtion and PrévAlim version 3.x (2005) software based on our own chemical analysis 
of feeds and using our own coefficients of rumen protein degradability $\left(\operatorname{deg}_{\mathrm{p}}\right)$ and intestinal protein digestibility $\left(\mathrm{dsi}_{\mathrm{p}}\right)$ for concentrate components. For milk replacer, $\operatorname{deg}_{\mathrm{P}}=0.01$ (due to the function of reticular groove) and $\mathrm{dsi}_{\mathrm{P}}=0.95$ values were assumed. The liveweight of calves was controlled for two successive days at the beginning of the experiment, at weaning and at the end of the experiment. Calves were kept in individual cages (Alfa Laval) with perforated wooden floors bedded with straw and equipped with automatic drinkers and feeding troughs. At the end of the experiment, 4 bulls from each group were slaughtered after 24-h feed withdrawal to sample rumen contents and sections of rumen wall.

\section{Sampling}

Samples of individual feeds in the mixtures and samples of the mixtures were taken twice during the experiment. Representative samples for analysis were prepared from feed refusals. Blood and faecal samples were taken at two-week intervals from four calves of each group. Blood was collected from the jugular vein, $4 \mathrm{~h}$ after the morning feeding, into $9 \mathrm{ml}$ clot activator tubes (Vacuette) and centrifuged at $3500 \mathrm{rpm}$. Serum was stored at $-18^{\circ} \mathrm{C}$. Representative samples of faeces were collected into plastic containers and frozen at $-18^{\circ} \mathrm{C}$. Faeces were dried for $48 \mathrm{~h}$ at $55^{\circ} \mathrm{C}$ and ground. Samples of rumen contents were taken postmortem from 4 calves of each group into plastic tubes and preserved with $24 \%$ metaphosphoric acid. Sections of rumen wall were taken from the middle part of the dorsal and ventral sac and stored in formalin.

\section{Chemical analyses of feeds and biological material}

Nutrient content of feed and feed refusals was determined according to AOAC (1997). VFA were determined after centrifugation of water filtrates with metaphosphoric acid (5:1) using VARIAN 3400 chromatograph (column CP-Wax $58,25 \mathrm{~m}$ x $0.53 \mathrm{~mm}$, injection volume $1.0 \mu \mathrm{l}$; temperature program: $90-200^{\circ} \mathrm{C}$; injector temperature $200^{\circ} \mathrm{C}$; detector temperature $260^{\circ} \mathrm{C}$, helium as carrier gas) using an $8200 \mathrm{CX}$ autosampler and a computer data processing system. Measurements of rumen content $\mathrm{pH}$ were taken directly after slaughter using an Elmetron $\mathrm{CP}-411$ potentiometer. Serum BHBA in the calves was determined spectrophotometrically on a Beckman DU-600 instrument, using commercial reagents (Randox). Starch in faecal samples was determined according to Faisant et al. (1995).

Determination of protein and starch degradability in the rumen and small intestine

Effective rumen degradability of crude protein $\left(\operatorname{deg}_{\mathrm{p}}\right)$ and starch $\left(\operatorname{deg}_{\mathrm{S}}\right)$, and 
intestinal digestibility of rumen-undegradable protein $\left(\mathrm{dsi}_{\mathrm{p}}\right)$ and starch $\left(\mathrm{dsi}_{\mathrm{S}}\right)$ were determined for the experimental feeds and concentrate mixtures on three ruminally and duodenally fistulated dry cows of the Polish Holstein-Friesian breed with an average body weight of $715 \pm 50 \mathrm{~kg}$. Rolled grains were incubated in the rumen. The incubation mixtures were prepared manually in amounts of $1 \mathrm{~kg}$ by weighing individual feeds in accordance with percentage composition of the mixtures. Daily ration for fistulated cows was, kg: meadow hay 6 and concentrate mixture 2.56, containing, $\%$ : barley 44 , wheat bran 40 , soyabean meal 12 , vitamin-mineral premix 3 and ground limestone 1 . The ration was formulated to meet maintenance requirements (about $0.5 \mathrm{~kg}$ milk/day). Deg coefficients were determined in sacco according to Michalet-Doreau et al. (1987), and dsi using the mobile bag technique according to Peyrand et al. (1988).

\section{Microscopic analysis of histological preparations of rumen wall}

Rumen tissue samples were determined according to Lesmeister et al. (2004) from dorsal and ventral part of the rumen. The tissue sections were formalin fixed, routinely processed with tissue processors by Shandon Inc. (UK) and embedded in paraffin. The tissue block were cut into $2 \mu \mathrm{m}$ thick sections and stained by hematoxillin-eosin method. The images were acquired using a Axioscope microscope (Zeiss GmbH, Germany) equipped with Plan-Neofluar 2.5x lens (Zeiss $\mathrm{GmbH}$, Germany) and CCD camera ZVS-47DE (Optronics Inc., USA). The camera was connected by a RGB line to GraBIT PCI framegrabber card (Soft Imaging Systems GmbH, Germany), installed on a standard PC. The measurements were done with AnalySIS 3.2 pro image analysis system (Soft Imaging Systems GmbH, Germany). Twenty well preserved papillae were chosen. The operator interactively marked their long and the short axis, measuring them with arbitrary distance tool of image analysis system. The results were stored to a text file for analysis.

\section{Statistical analysis}

Body weight, weight gains in different experimental periods, and the serum concentration of $\beta$-hydroxybutyric acid and faecal starch (\%DM) were analysed statistically using the MIXED procedure (SAS, 2001) of one-way analysis of variance with repeated measures based on the following model:

$$
\mathrm{Y}_{\mathrm{ijk}}=\mu+\alpha_{\mathrm{i}}+\mathrm{d}_{\mathrm{ij}}+\tau_{\mathrm{k}}+(\alpha \tau)_{\mathrm{ik}}+\mathrm{e}_{\mathrm{ijk}}
$$

where: $Y_{\mathrm{ijk}}$ - dependent variable, $\mu$ - overall mean, $\alpha_{\mathrm{i}}$ - fixed effect of group, $\mathrm{d}_{\mathrm{ij}}-$ random effect of jth animal in group, $\tau_{\mathrm{k}}-$ fixed effect of kth age, $(\alpha \tau)_{\mathrm{ik}}$ - effect of fixed group $\left(\alpha_{\mathrm{i}}\right)$ and age $(\mathrm{k})$ interaction, $\mathrm{e}_{\mathrm{ijk}}$-random error, $\mathrm{i}=\mathrm{B}, \mathrm{M}_{\mathrm{D}}, \mathrm{BM}_{\mathrm{S}}$ or $\mathrm{M}_{\mathrm{D}} \mathrm{M}_{\mathrm{S}}$, 
$\mathrm{k}($ weeks $)=2,4,6,8,10,12$.

Differences between the means were determined using orthogonal contrasts and Bonferroni's test. The other results were analysed using one-way analysis of variance and Duncan's test with differences considered significant if $\mathrm{P} \leq 0.05$.

\section{RESULTS}

Chemical composition of feeds. Diets contained similar levels of protein and energy and contained (per kg DM) an average of: $187 \pm 3 \mathrm{~g} \mathrm{CP}, 109 \pm 4.0 \mathrm{~g}$ PDI, $1.07 \pm 0.03$ UFL. Diets for groups $M_{D}$ and $M_{D} M_{S}$ with dry maize grain contained more starch than diets for the other groups, especially that for group B with barley as a source of starch (Table 2).

Table 2. Chemical composition (\% of DM) and nutritive value of concentrates (in $1 \mathrm{~kg} \mathrm{DM}$ )

\begin{tabular}{|c|c|c|c|c|c|c|c|c|c|c|}
\hline Item & $\begin{array}{c}\text { Dry } \\
\text { matter }\end{array}$ & $\begin{array}{l}\text { Crude } \\
\text { protein }\end{array}$ & $\begin{array}{c}\text { Ether } \\
\text { extract }\end{array}$ & $\begin{array}{c}\text { Crude } \\
\text { fibre }\end{array}$ & Starch & $\begin{array}{c}\text { N-free } \\
\text { extractives }\end{array}$ & Ash & $\frac{\text { PDIN }}{\text { in } 1}$ & $\begin{array}{l}\text { PDIE } \\
\mathrm{kg} \text { of }\end{array}$ & $\frac{\mathrm{UFL}}{\mathrm{DM}}$ \\
\hline \multicolumn{11}{|c|}{ 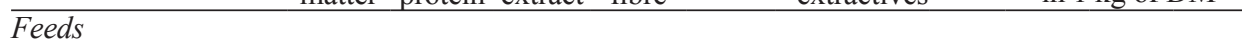 } \\
\hline milk replacer ${ }^{1}$ & 97.3 & 20.5 & 20.4 & 1.03 & no & 49.8 & 8.3 & $203^{1}$ & & 1.63 \\
\hline barley & 88.3 & 11.6 & 1.9 & 4.3 & & 79.8 & 2.4 & 70 & 81 & 1.10 \\
\hline maize grain, dry & 87.6 & 10.4 & 4.1 & 2.5 & no & 81.3 & 1.7 & 74 & 79 & 1.20 \\
\hline maize grain, silage ${ }^{2}$ & 71.6 & 13.4 & 2.5 & 1.9 & no & 82.2 & 1.4 & 82 & 67 & 1.20 \\
\hline oats & 88.1 & 11.1 & 5.4 & 1.4 & no & 79.3 & 2.8 & 74 & 76 & 0.86 \\
\hline soyabean meal & 89.5 & 48.3 & 2.2 & 3.2 & no & 39.4 & 6.9 & 344 & 245 & 1.23 \\
\hline \multicolumn{11}{|l|}{ Concentrates for groups } \\
\hline B & 88.6 & 19.0 & 2.5 & 5.5 & 41 & 28.5 & 3 & 128 & 113 & 1.04 \\
\hline$M_{D}$ & 87.2 & 18.4 & 3.7 & 4.5 & 48.9 & 24.3 & 3. & 130 & 111 & 1.10 \\
\hline $\mathrm{BM}_{\mathrm{s}}$ & 83.9 & 18.8 & 2.7 & 5.0 & 46.0 & 24.3 & 3. & 125 & 105 & 1.06 \\
\hline $\mathrm{M}_{\mathrm{D}} \mathrm{M}_{\mathrm{s}}$ & 83.7 & 18.8 & 8.6 & 12.1 & 49.5 & 7.71 & 3.3 & 129 & 106 & 1.10 \\
\hline
\end{tabular}

PDI for milk replacer corresponds to digested crude protein; ${ }^{2}$ fermentation products $=25.3 \mathrm{~g} / \mathrm{kg}$ feed (lactic acid, acetic acid)

Coefficients of ruminal and intestinal digestibility of protein and starch. Compared to barley diets (groups $\mathrm{B}$ and $\mathrm{BM}_{\mathrm{S}}$ ), diets containing dry maize grain (groups $M_{D}$ and $M_{D} M_{S}$ ) were characterized by lower effective rumen degradability of protein and starch, lower true digestibility of protein and starch in the small intestine, and lower total tract digestibility of these nutrients (Table 3). The course of curves (Figure 1) confirms more rapid starch degradation during rumen incubation for barley or barley and ensiled maize diets and much slower degradation of dry maize diets. 
Table 3. Effective rumen degradability of crude protein $\left(\operatorname{deg}_{\mathrm{p}}\right)$ and $\operatorname{starch}\left(\mathrm{dsi}_{\mathrm{S}}\right)$ and true intestinal digestibility of undegraded dietary protein $\left(\mathrm{dsi}_{\mathrm{p}}\right)$ and $\operatorname{starch}\left(\mathrm{dsi}_{\mathrm{S}}\right)$

\begin{tabular}{|c|c|c|c|c|c|c|c|}
\hline \multirow[b]{2}{*}{ Item } & \multicolumn{4}{|c|}{ Concentrates for groups } & \multicolumn{3}{|c|}{ Grains } \\
\hline & B & $M_{D}$ & $\mathrm{BM}_{\mathrm{s}}$ & $\mathrm{M}_{\mathrm{D}} \mathrm{M}_{\mathrm{S}}$ & $\begin{array}{l}\text { barley, } \\
\text { rolled }\end{array}$ & $\begin{array}{l}\text { dry rolled } \\
\text { maize }\end{array}$ & $\begin{array}{l}\text { high moisture } \\
\text { maize }\end{array}$ \\
\hline$\overline{d e g}$ & 0.77 & 0.59 & 0.68 & 0.66 & 0.70 & 0.68 & 0.82 \\
\hline $\mathrm{dsi}_{\mathrm{S}}$ & 0.86 & 0.66 & 0.94 & 0.65 & 0.85 & 0.95 & 0.79 \\
\hline dwdt & 97.39 & 72.66 & 95.67 & 89.48 & 96.0 & 80.6 & 95.94 \\
\hline $\operatorname{deg}_{p}$ & 0.89 & 0.36 & 0.83 & 0.53 & 0.96 & 0.65 & 0.84 \\
\hline $\mathrm{dsi}_{\mathrm{S}}$ & 0.93 & 0.29 & 0.92 & 0.54 & 0.92 & 0.24 & 0.98 \\
\hline dwdt & 99.54 & 54.96 & 97.14 & 58.46 & 99.00 & 87.45 & 98.78 \\
\hline
\end{tabular}

total tract digestibility, $\%$

A

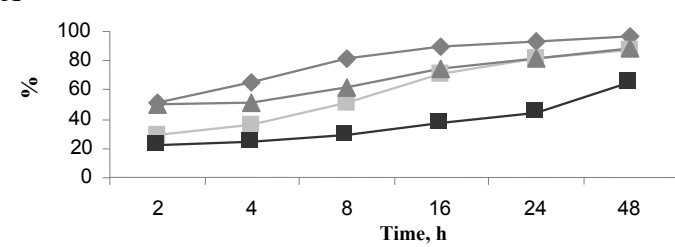

B

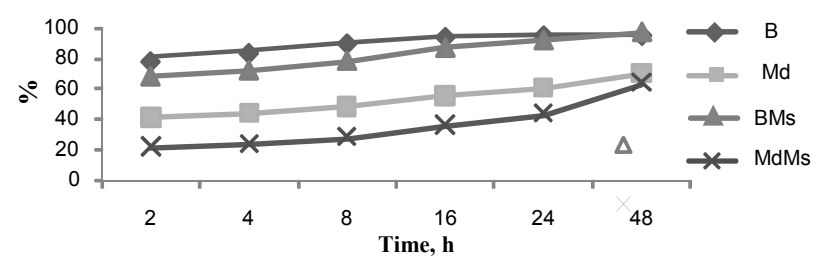

Figure 1. Rumen degradability of protein (A) and starch (B) during incubation

Rearing performance of calves. No significant $(\mathrm{P}>0.05)$ differences were found between the groups for body weight and daily weight gains in different periods of the experiment (Table 4). The age of calves had a significant effect on body weight and daily weight gains $(\mathrm{P}<0.01)$. There was no significant group $\mathrm{x}$ age interaction. During the liquid feeding period, calves receiving the diets with only dry grain (groups $\mathrm{B}$ and $\mathrm{M}_{\mathrm{D}}$ ) had a significantly $(\mathrm{P}=0.02)$ lower intake of milk replacer (Table 5). Daily starch intake increased with each week of calves' age with non-significant differences between the groups until 8 weeks. After this period, calves receiving dry maize diets in successive weeks (groups $M_{D}$ and $M_{D} M_{S}$ ) had a much higher intake of starch compared to calves from groups $\mathrm{B}$ and $\mathrm{BM}_{\mathrm{S}}$ (Table 6). A significant group $\mathrm{x}$ age interaction was found. 
Table 4. Liveweight and daily liveweight gains

\begin{tabular}{|c|c|c|c|c|c|c|c|}
\hline \multirow[b]{2}{*}{ Item } & \multicolumn{4}{|c|}{ Concentrates for groups } & \multicolumn{3}{|c|}{ Grains } \\
\hline & B & $M_{D}$ & $\mathrm{BM}_{\mathrm{S}}$ & $\mathrm{M}_{\mathrm{D}} \mathrm{M}_{\mathrm{S}}$ & group & age & $\begin{array}{l}\text { group } \\
\mathrm{x} \text { age }\end{array}$ \\
\hline $\begin{array}{l}\text { Liveweight gain, } \mathrm{kg} \\
\text { initial } \\
\text { at weaning }\left(56^{\text {th }} \text { day of age }\right) \\
\text { final }\end{array}$ & $\begin{array}{c}47.7 \\
75.2 \\
111.0\end{array}$ & $\begin{array}{c}46.7 \\
76.5 \\
114.1\end{array}$ & $\begin{array}{c}44.2 \\
73.8 \\
116.2\end{array}$ & $\begin{array}{c}44.4 \\
73.8 \\
110.6\end{array}$ & 0.75 & $<0.01$ & 0.19 \\
\hline $\begin{array}{l}\text { Daily liveweight gains, } g \cdot d a y^{-1} \\
\text { before weaning } \\
\text { after weaning } \\
\text { from beginning to end }\end{array}$ & $\begin{array}{r}598 \\
1053 \\
791\end{array}$ & $\begin{array}{r}648 \\
1106 \\
842\end{array}$ & $\begin{array}{r}650 \\
1247 \\
906\end{array}$ & $\begin{array}{r}646 \\
1082 \\
833\end{array}$ & 0.43 & $<0.01$ & 0.3 \\
\hline
\end{tabular}

Table 5. Feed and nutrient intake and utilization in different periods of the experiment

\begin{tabular}{|c|c|c|c|c|c|c|}
\hline Item & $\mathrm{B}$ & $M_{D}$ & $\mathrm{BM}_{\mathrm{s}}$ & $\mathrm{M}_{\mathrm{D}} \mathrm{M}_{\mathrm{S}}$ & $\mathrm{P}$ & SE \\
\hline \multicolumn{7}{|l|}{ Feed intake } \\
\hline milk replacer (to $56^{\text {th }}$ day of age), $\mathrm{kg}$. calf ${ }^{1}$ & $52.44^{\mathrm{A}}$ & $51.98^{\mathrm{A}}$ & 53.36 & $53.36^{\mathrm{B}}$ & 0.01 & 0.21 \\
\hline $\begin{array}{l}\text { milk replacer (to } 56^{\text {th }} \text { day of age), } \mathrm{kg} \cdot \mathrm{d}^{-1} \\
\text { concentrate, from beginning to }\end{array}$ & $1.14^{\mathrm{b}}$ & $1.13^{\mathrm{b}}$ & $1.17^{\mathrm{a}}$ & $1.17^{\mathrm{a}}$ & 0.02 & 0.004 \\
\hline $90^{\text {th }}$ day of age, $\mathrm{kg}^{\text {calf }}{ }^{-1}$ & 130.4 & 130.2 & 125.5 & 120.9 & 0.63 & 2.91 \\
\hline concentrate, $\mathrm{kg} \cdot \mathrm{d}^{-1}$ & 1.63 & 1.64 & 1.59 & 1.53 & 0.62 & 0.04 \\
\hline dry matter, $\mathrm{kg} \cdot \mathrm{d}^{-1}$ & 2.06 & 2.07 & 1.99 & 1.94 & 0.23 & 0.03 \\
\hline crude protein, $g \cdot \mathrm{d}^{-1}$ & 403 & 406 & 403 & 389 & 0.64 & 6.05 \\
\hline starch, $g d^{-1}$ & $576^{\mathrm{a}}$ & $703^{b}$ & $601^{\mathrm{a}}$ & $622^{\mathrm{a}}$ & 0.03 & 15.68 \\
\hline PDIN, $g \cdot d^{-1}$ & 321 & 320 & 291 & 296 & 0.11 & 4.36 \\
\hline PDIE, $g \cdot d^{-1}$ & $306^{\mathrm{a}}$ & $307^{\mathrm{ab}}$ & $289^{\mathrm{bc}}$ & $281^{\mathrm{c}}$ & 0.02 & 4.16 \\
\hline $\mathrm{UFL}^{-1}$ & 1.65 & 1.70 & 1.65 & 1.63 & 0.29 & 0.017 \\
\hline \multicolumn{7}{|l|}{ Feed utilization per $\mathrm{kg}$ liveweight gain } \\
\hline concentrate, $\mathrm{kg}$ & $2.06^{\mathrm{a}}$ & $1.95^{\mathrm{ab}}$ & $1.76^{\mathrm{c}}$ & $1.84^{\mathrm{bc}}$ & 0.02 & 0.04 \\
\hline dry matter, $\mathrm{kg}$ & $2.61^{\mathrm{a}}$ & $2.47^{\mathrm{ab}}$ & $2.2^{\mathrm{c}}$ & $2.33^{\mathrm{bc}}$ & 0.01 & 0.04 \\
\hline crude protein, $\mathrm{g}$ & $510^{\mathrm{a}}$ & $482.5^{\mathrm{ab}}$ & $445^{\mathrm{b}}$ & $468^{\mathrm{ab}}$ & 0.03 & 8.17 \\
\hline starch, g & $728^{\mathrm{bc}}$ & $835^{\mathrm{a}}$ & $664^{\mathrm{c}}$ & $747^{\mathrm{b}}$ & 0.01 & 16.04 \\
\hline PDI, g & $387^{\mathrm{a}}$ & $364.7^{\mathrm{ab}}$ & $321^{\mathrm{c}}$ & $338^{\mathrm{bc}}$ & 0.01 & 6.88 \\
\hline UFL & 2.09 & 2.02 & 1.82 & 1.96 & 0.06 & 0.04 \\
\hline
\end{tabular}

without letters - $\mathrm{P}>0.05 ;{ }^{\mathrm{a}, \mathrm{b}, \mathrm{c}}-\mathrm{P} \leq 0.05$

Histological examination of the rumen wall. In the dorsal part of the rumen, the papillae of calves fed barley grain diets, especially in group B, were longer $(P \leq 0.05)$ than those of calves receiving dry maize grain diets $\left(M_{D}\right.$ and $\left.M_{D} M_{S}\right)$. In the ventral part no significant differences in the length of rumen papillae were found, but numerical values obtained in group B were markedly smaller than in the other groups. No statistically significant differences were found in the width of rumen papillae or in the coefficient of elongation. In the ventral part in group B, a markedly thinner $(\mathrm{P}=0.02)$ ruminal wall was founding relation to other groups, 
Table 6. Starch intake in successive weeks, $\mathrm{g} \cdot \mathrm{d}^{-1}$

\begin{tabular}{|c|c|c|c|c|c|c|c|c|c|c|c|c|}
\hline \multirow{4}{*}{ Item } & \multicolumn{4}{|c|}{ Groups } & \multicolumn{3}{|c|}{$\mathrm{P}$} & \multicolumn{5}{|c|}{ Contrast } \\
\hline & & & & & & & Group & B & $\mathrm{M}_{\mathrm{D}}$ & $\mathrm{B}$ & $\mathrm{BM}_{\mathrm{S}}$ & $\mathrm{M}_{\mathrm{D}}$ \\
\hline & B & $M_{D}$ & $\mathrm{BM}_{\mathrm{s}}$ & $\mathrm{M}_{\mathrm{D}} \mathrm{M}_{\mathrm{S}}$ & group & Age & $\mathrm{x}$ & vs & vs & vs & vs & vs \\
\hline & & & & & & & age & $\mathrm{BM}_{\mathrm{s}}$ & $\mathrm{M}_{\mathrm{D}} \mathrm{M}_{\mathrm{S}}$ & $\mathrm{M}_{\mathrm{D}}$ & $\mathrm{M}_{\mathrm{D}} \mathrm{M}_{\mathrm{S}}$ & $\mathrm{BM}_{\mathrm{S}}$ \\
\hline Age, weeks & & & & & 0.01 & 0.01 & 0.01 & & & & & \\
\hline 2 & 20.2 & 19.0 & 23.1 & 17.3 & & & & NS & NS & NS & NS & NS \\
\hline 4 & 37.4 & 46.4 & 35.1 & 42.2 & & & & NS & NS & NS & NS & NS \\
\hline 6 & 100.4 & 102.6 & 98.8 & 93.3 & & & & NS & NS & NS & NS & NS \\
\hline 8 & 356.9 & 395 & 343.8 & 393.2 & & & & NS & NS & NS & NS & NS \\
\hline 10 & 952.6 & 1235.7 & 923.0 & 1005.8 & & & & NS & $* * *$ & $* * *$ & NS & $* * *$ \\
\hline 12 & 1218.9 & 1430.2 & 1330.5 & 1340.7 & & & & $*$ & $* * *$ & $* * *$ & NS & $* * *$ \\
\hline 13 & 1408.8 & 1601.6 & 1397.48 & 1630.9 & & & & NS & NS & $* * *$ & $* * *$ & $* * *$ \\
\hline
\end{tabular}

NS - P $>0.10 ; *$ - $\mathrm{P} \geq 0.06-0.10 ; * *-\mathrm{P} \leq 0.05 ; * * *-\mathrm{P} \leq 0.01$

with significant differences found only for groups $\mathrm{BM}_{S}$ and $\mathrm{M}_{\mathrm{D}} \mathrm{M}_{\mathrm{S}}$. There were no differences between the groups in the dorsal part of the rumen (Table 7).

Table 7. Length, width and thickness of calves' papillae in dorsal and ventral parts of the rumen, 90 days of age

\begin{tabular}{|c|c|c|c|c|c|c|}
\hline Item & B & $\mathrm{BM}_{\mathrm{O}}$ & $\mathrm{BM}_{\mathrm{s}}$ & $\mathrm{M}_{\mathrm{D}} \mathrm{M}_{\mathrm{s}}$ & $\mathrm{P}$ & SE \\
\hline \multicolumn{7}{|l|}{ Length, $\mathrm{cm}$} \\
\hline dorsal sac of the rumen & $2.07^{\mathrm{a}}$ & $1.16^{\mathrm{b}}$ & $1.62^{\mathrm{a}}$ & $1.11^{\mathrm{b}}$ & 0.05 & 0.14 \\
\hline ventral sac of the rumen & 1.78 & 2.03 & 2.53 & 2.29 & 0.62 & 0.02 \\
\hline \multicolumn{7}{|l|}{ Width, $\mathrm{cm}$} \\
\hline dorsal sac of the rumen & 0.40 & 0.47 & 0.45 & 0.44 & 0.62 & 0.02 \\
\hline ventral sac of the rumen & 0.45 & 0.48 & 0.44 & 0.36 & 0.56 & 0.03 \\
\hline \multicolumn{7}{|l|}{ Coefficient of elongation ${ }^{1}$} \\
\hline dorsal sac of the rumen & 0.9 & 0.44 & 0.31 & 0.39 & 0.16 & 0.03 \\
\hline ventral sac of the rumen & 0.25 & 0.24 & 0.17 & 0.16 & 0.33 & 0.02 \\
\hline \multicolumn{7}{|l|}{ Rumen wall thickness, mm } \\
\hline dorsal sac of the rumen & 3.12 & 3.56 & 3.96 & 3.30 & 0.72 & 0.25 \\
\hline ventral sac of the rumen & $2.38^{\mathrm{b}}$ & $3.63^{\mathrm{ab}}$ & $4.87^{\mathrm{a}}$ & $4.14^{\mathrm{a}}$ & 0.02 & 0.32 \\
\hline
\end{tabular}

Volatile fatty acids and $\mathrm{pH}$ of rumen fluid. No significant differences were found between the calf groups in total VFA concentration in ruminal fluid $(\mathrm{P}=0.76)$, although numerical values for the $\mathrm{BM}_{\mathrm{S}}$ and $\mathrm{M}_{\mathrm{D}} \mathrm{M}_{\mathrm{S}}$ groups were markedly higher (Table 8). Compared to groups $\mathrm{B}$ and $\mathrm{M}_{\mathrm{D}}$, the use of ensiled maize grain in concentrate mixtures for calves in groups $\mathrm{BM}_{\mathrm{S}}$ and $\mathrm{M}_{\mathrm{D}} \mathrm{M}_{\mathrm{S}}$ reduced the $\mathrm{pH}$ of rumen contents $(\mathrm{P}<0.01)$.

Serum concentration of $\beta$-hydroxybutyric acid (BHBA). Serum concentration of BHBA was dependent on the age of the calves $(\mathrm{P} \leq 0.01)$, but not on the source of starch (Table 9). After weaning, calves fed diets containing ensiled maize grain 
showed a tendency at 10 and 12 weeks of age towards higher serum concentration of BHBA compared to the other groups.

Table 8. Total VFA, proportion of VFA and $\mathrm{pH}$ of the rumen fluid

\begin{tabular}{|c|c|c|c|c|c|c|}
\hline \multirow{2}{*}{ Item } & \multicolumn{4}{|c|}{ Groups } & \multirow{2}{*}{$\mathrm{P}$} & \multirow{2}{*}{ SE } \\
\hline & $\mathrm{B}$ & $M_{0}$ & $\mathrm{BM}_{\mathrm{s}}$ & $\mathrm{M}_{\mathrm{D}} \mathrm{M}_{\mathrm{s}}$ & & \\
\hline Total VFA, $\mathrm{mmol} \cdot \mathrm{l}^{-1}$ & 73.7 & 70.6 & 88.65 & 90.23 & 0.76 & 0.4 \\
\hline \multicolumn{7}{|c|}{ Molar proportion of $V F A, \% \mathrm{~mol}$} \\
\hline $\mathrm{C} 2$ & 51.63 & 54.11 & 48.18 & 50.1 & 0.61 & 1.85 \\
\hline $\mathrm{C} 3$ & 31.91 & 32.6 & 35.77 & 34.07 & 0.92 & 2.13 \\
\hline iso-C4 & 3.44 & 2.86 & 1.07 & 1.07 & 0.63 & 0.38 \\
\hline $\mathrm{C} 4$ & 6.95 & 6.22 & 11.05 & 9.78 & 0.78 & 1.29 \\
\hline iso-C5 & 3.44 & 3.01 & 1.86 & 1.83 & 0.80 & 0.47 \\
\hline C5 & 2.62 & 1.19 & 3.07 & 3.15 & 0.30 & 0.41 \\
\hline $\mathrm{C} 2 / \mathrm{C} 3$ & 1.62 & 1.66 & 1.35 & 1.47 & 0.76 & 0.35 \\
\hline $\mathrm{C} 3 / \mathrm{C} 4$ & 4.59 & 5.24 & 3.24 & 3.48 & 0.86 & 0.56 \\
\hline $\mathrm{pH}$ & $5.95^{\mathrm{A}}$ & $6.26^{\mathrm{A}}$ & $5.20^{\mathrm{B}}$ & $5.00^{\mathrm{B}}$ & 0.01 & 0.09 \\
\hline
\end{tabular}

Table 9. Serum concentration of $\beta$-hydroxybutyric acid in calves, $\mathrm{mmol} / \mathrm{l}$

\begin{tabular}{|c|c|c|c|c|c|c|c|c|c|}
\hline \multirow{2}{*}{ Group } & \multicolumn{6}{|c|}{ Age of calves, weeks } & \multicolumn{3}{|c|}{$\mathrm{P}$} \\
\hline & 2 & 4 & 6 & 8 & 10 & 12 & group & time & group $\mathrm{x}$ time \\
\hline$\overline{\mathrm{BHBA}, \mathrm{mmol} / \mathrm{l}}$ & & & & & & & 0.55 & 0.01 & 0.32 \\
\hline $\mathrm{B}$ & 0.00 & 0.00 & 0.06 & 0.07 & 0.14 & 0.29 & & & \\
\hline $\mathrm{M}_{\mathrm{D}}$ & 0.00 & 0.09 & 0.065 & 0.05 & 0.14 & 0.24 & & & \\
\hline $\mathrm{BM}_{\mathrm{s}}$ & 0.00 & 0.00 & 0.00 & 0.05 & 0.18 & 0.26 & & & \\
\hline $\mathrm{MDM}_{\mathrm{S}}$ & 0.00 & 0.00 & 0.00 & 0.02 & 0.35 & 0.32 & & & \\
\hline
\end{tabular}

Faecal starch. Faecal starch percentage depended on both the age of calves $(\mathrm{P}=0.04)$ and the source of starch used $(\mathrm{P}=0.06)$ (Table 10). Calves receiving dry maize grain, mainly the $M_{D}$ group, had higher faecal starch losses in successive weeks of age than the other groups, in particular the calves receiving barley diets (groups $\mathrm{B}$ and $\mathrm{BM}_{\mathrm{D}}$ ).

Table 10. Faecal starch content, \%

\begin{tabular}{|c|c|c|c|c|c|c|c|c|c|}
\hline \multirow[b]{2}{*}{ Group } & \multicolumn{6}{|c|}{ Age, weeks } & \multicolumn{3}{|c|}{$P$} \\
\hline & 2 & 4 & 6 & 8 & 10 & 12 & group & age & group $\mathrm{x}$ age \\
\hline & & & & & & & 0.06 & 0.04 & 0.09 \\
\hline B & 0.41 & 0.00 & 0.00 & 6.02 & $0.59^{\mathrm{b}}$ & $0.87^{\mathrm{b}}$ & & & \\
\hline$M_{D}$ & 0.68 & 0.33 & 0.58 & 5.49 & $7.79^{a}$ & $12.15^{\mathrm{a}}$ & & & \\
\hline $\mathrm{BM}_{\mathrm{s}}$ & 0.11 & 0.29 & 0.00 & 7.79 & $0.46^{\mathrm{b}}$ & $1.94^{\mathrm{b}}$ & & & \\
\hline $\mathrm{M}_{\mathrm{D}} \mathrm{M}_{\mathrm{S}}$ & 2.1 & 0.11 & 0.00 & 1.25 & $3.84^{\mathrm{ab}}$ & $9.67^{\mathrm{a}}$ & & & \\
\hline
\end{tabular}

without letters - $\mathrm{P}>0.05 ; \mathrm{a}, \mathrm{b}-\mathrm{P} \leq 0.05$ 


\section{DISCUSSION}

Although differences between the groups in daily weight gains were not significant, higher numerical values were obtained for calves receiving maize diets (groups $M_{D}, B_{S}, M_{D} M_{S}$ ) compared to barley alone (B), especially in group $B_{S}$ (Table 5). This was probably due to better intestinal digestibility of bypass protein and starch in ensiled maize grain and barley from the diet for group $\mathrm{BM}_{\mathrm{S}}$. When calves were fed mixtures containing dry maize grain (groups $M_{D}$ and $M_{D} M_{S}$ ), probably more of this feed passed to the small intestine but its intestinal digestibility was poorer. This is shown by the values for effective rumen degradability of starch and protein, intestinal digestibility of starch and protein, and total tract digestibility of starch and protein, which were lower for dry maize diets compared to the diets for groups $\mathrm{B}$ and $\mathrm{BM}_{\mathrm{S}}$, as well as by the protein and starch distribution curves for different diets in the rumen during incubation (Table 3, Figure 1).

Higher numerical values for daily weight gains in calves receiving dry maize grain diets compared to diets for group B may suggest that intestinal digestion of starch is energetically more efficient because of lower energy losses for heat and methane production in the rumen, while starch fermentation in the rumen and gluconeogenesis result in high energy losses (Nocek and Tamminga, 1991). However, the production results obtained so far are not conclusive. Some authors observed better production results when giving rumen-protected feeds (Abdergadir et al., 1996), while others (Zhang et al., 2007) obtained better growth for calves receiving readily available feed. The benefits of lower starch and protein degradation in the rumen can be attributed to higher intestinal availability of energy and protein, whereas higher starch degradation could result in better development of rumen papillae and thus improve the absorptive capacity of rumen mucosa.

The beneficial effect of feeding the barley and ensiled maize grain diet on production results is also indicated by lower faecal starch losses compared to calves receiving the dry maize grain diets (Table 10). On the other hand, however, calves from group $\mathrm{BM}_{\mathrm{S}}$ had a generally lower intake of starch in successive weeks compared to those fed dry maize diets (Table 6). Faecal starch losses could therefore be lower, especially since it was better digested in the total tract. At the same time, feeding barley together with ensiled maize grain $\left(\right.$ group $\mathrm{BM}_{\mathrm{S}}$ ) considerably improved intestinal digestibility of protein, compared to calves from group B receiving barley diets, which could, to some extent, have a beneficial effect on body weight gains. However, the addition of ensiled maize grain to the concentrate diets for calves reduced faecal starch percentage compared to the group receiving dry maize grain. Reduction of faecal starch losses in adult ruminants using ensiled maize grain was observed by Archibeque et al. (2006). Slightly higher numerical values obtained for daily weight gains and feed conversion in calves from group $\mathrm{BM}_{\mathrm{S}}$, in relation 
to the other groups suggests that ensiled maize grain combined with barley has a more beneficial effect on calf rearing performance than dry barley or maize grain, or feeding a diet containing both dry and ensiled maize grain.

The increase in milk replacer intake by about $3 \%$ when feeding ensiled maize grain diets $(\mathrm{P}=0.02)$ suggests that it could exert an effect on dry matter intake. However, Khan et al. (2007), who gave different starch sources in calf concentrates, found no differences in milk intake. The introduction of ensiled maize grain into feed mixtures had no significant effect on feed and dry matter intake during the whole experimental period, although slightly lower numerical values were obtained in groups $\mathrm{BM}_{\mathrm{S}}$ and $\mathrm{M}_{\mathrm{D}} \mathrm{M}_{\mathrm{S}}$ compared to barley (group B) or dry maize (group $\mathrm{M}_{\mathrm{D}}$ ). It could be due to the lower $\mathrm{pH}$ of rumen contents (Suarez et al., 2006a). It cannot be excluded, however, that slightly lower dry matter intake of both PDI and starch when feeding ensiled maize grain could result from differences in the content of these nutrients in the starch sources studied.

The tendency towards better feed conversion, shown by calves receiving the barley and ensiled maize diet compared to the other groups, confirms the possible effect of this mixture on calf rearing performance.

The significant $(\mathrm{P}<0.01)$ decrease in $\mathrm{pH}$ of rumen contents in calves from groups $\mathrm{BM}_{\mathrm{S}}$ and $\mathrm{M}_{\mathrm{D}} \mathrm{M}_{\mathrm{S}}$ compared to group $\mathrm{M}_{\mathrm{D}}$ could result from more rapid fermentation of starch from ensiled maize grain to VFA. Khan et al. (2008), who used isostarch $(25 \% \mathrm{DM})$ diets containing different starch sources, found statistically significant differences in the ruminal VFA concentration. The diet containing only dry maize grain as the major source of starch was characterized by the lowest ruminal starch degradation and the numerical value for total VFA in calves from group $M_{D}$ was lower $(\mathrm{P}>0.05)$ than in those fed ensiled maize grain diets. Despite the high ruminal digestibility of starch from the control diet (B), $\mathrm{pH}$ of rumen contents and total VFA concentration were similar to those obtained when the $M_{D}$ diet was fed. It was probably due to the higher ruminal concentration of ammonia-N as a result of more rapid protein degradation than in the other groups (Khan et al., 2007). Because various amounts of straw were found after slaughter in the calves rumen it can be presumed that keeping calves on straw bedding could have a certain effect on $\mathrm{pH}$ and VFA concentration (Zhang et al., 2007). The greater numerical values $(\mathrm{P}>0.05)$ for propionic and butyric acids and the lower $\mathrm{C}_{2}: \mathrm{C}_{3}$ ratio found in calves fed the ensiled maize diet, especially in combination with barley $\left(\right.$ group $\mathrm{BM}_{\mathrm{S}}$ ), suggests a greater ruminal degradation of starch than fibre compared to the other groups. Hall and Larson (2004) reported that in situ digestibility of fibre may depend on the type of non-cell wall carbohydrates, their degradation in the rumen and their interaction with protein source. The concentration of propionic and butyric acids in the rumen depends mainly on the source of dietary starch (Suarez et al., 2006b; Khan et al., 2008). 
The results of the study concerning serum BHBA concentrations do not allow to conclude that the source of starch could have a significant effect on metabolic processes in rumen mucosa cells, whereas a clear increase in BHBA concentration was observed with age of animals. However, slightly higher numerical values of serum BHBA concentration than in the other groups, obtained BHBA at 10 and 12 weeks of age for calves fed ensiled maize grain diets suggest that this feed could positively affect ketogenesis. This could be associated with the greater absorption of butyric acid as a result of higher ruminal concentration of this acid. Compared to calves fed milk replacer alone, Suarez et al. (2006b) reported higher serum BHBA concentrations in 8-week-old calves receiving pectins or a mixture of different carbohydrates, but at 12 weeks of age they did not found any differences between the groups. Some authors found serum BHBA concentrations to increase with age and feed intake (Lesmeister and Heinrichs, 2004), but others failed to observe such a phenomenon (Suarez et al., 2006b). Quigley and Bernard (1992) reported that blood BHBA concentration between 28 and 42 days of age ranged from 0.22 to $0.62 \mathrm{mM} / 1$, while in the same period, Suarez et al. (2006b) observed much lower BHBA values, similar to those observed in the present study. Lane et al. (2000) demonstrated a similar increase in BHBA production in 42-day-old lambs fed milk alone or milk and concentrate mixture, which suggests that the presence of VFA may not be the only factor inducing the development of ketogenesis, and it may occur via ontogenesis or as a result of other factors. According to Lane et al. (2002), mRNA coding for acetyl-CoA thiolase, the first enzyme in the ketogenic pathway, increases with age regardless of the feeding used, while the mRNA level of 3-hydroxy-3methylglutaryl-CoA (HMG-CoA) synthetase, the second enzyme taking part in the regulation of ketogenesis, may be regulated by feeding only to 42 days of age, after which it increases 6-fold regardless of feeding and becomes stable.

Evans et al. (1973) report that higher stimulation of papillae growth in the dorsal rather than cranial or ventral part of the rumen may result from larger particles drifting and floating in the rumen. Ground barley is flat and has a large area, while maize grain breaks and crumbles during grinding and has a much smaller area. This is perhaps why calves receiving barley diets, especially those in group B, were characterized by better development of papillae in the dorsal part due to more intense fermentation in this part of the rumen, while in the ventral part the numerical values for length of rumen papillae were clearly smaller in this group than in the other groups. The development of rumen papillae could also be affected by the of dorsal papillae length for barley and ensiled maize grain feeding compared to calves fed dry maize diets. Zhang et al. (2007) observed differences in papillae length $(\mathrm{P}<0.05)$ when feeding calves diets differing in the rate of ruminal starch degradation. Lesmeister and Heinrichs (2004) state that compared to ground maize or whole maize grain, flaked maize improved the formation of rumen papillae 
length $(\mathrm{P}<0.05)$ when feeding calves diets differing in the rate of ruminal starch degradation. Lesmeister and Heinrichs (2004) state that compared to ground maize or whole maize grain, flaked maize improved the formation of rumen papillae and stimulated the growth of rumen mucosa in calves. No differences in papillae width were also observed in other feeding trials with calves (Beharka et al., 1998). However, Khan et al. (2008) found clear differences in the length, width and density of rumen papillae as well as in VFA proportions when feeding pelleted diets with different starch sources. Thinner wall of the ventral rumen in group B compared to the other groups may be indicative of the lower physical stimulation of the muscle layer in this part of the rumen by ground barley, which could float in the upper strata of the rumen.

\section{CONCLUSIONS}

The results obtained show that rolled ensiled maize grain can be successfully used in diets for calves reared from 10 to 90 days of age to replace ( $50 \%$ by weight) dry rolled barley or maize grain. However, slightly better production results are obtained when feeding a barley and ensiled maize grain diet, which is probably due to the better intestinal digestibility of protein and starch, as shown by higher intestinal digestibility of protein and starch as well as lower faecal starch losses. The addition of ensiled maize grain to the diets did not cause significant changes in rumen fermentation, although there was a slight increase in total VFA concentration and proportion of butyric acid, and a reduction in $\mathrm{pH}$ of rumen contents, and calves tended to have higher serum $\beta$-hydroxybutyric acid concentrations at 10 and 12 weeks of age. The replacement of dry grains with ensiled maize grain in the diets for calves did not have a favourable effect on rumen papillae development but improved wall thickness of the ventral ruminal sac.

\section{REFERENCES}

Abdelgadir I.E.O., Morril J.L., Higgins J.J., 1996. Effect of roasted soybeans and corn on performance and ruminal and blood metabolites of dairy calves. J. Dairy Sci. 79, 465-474

Archibeque S.L., Miller D.N., Freetly H.C., Ferrell C.L., 2006. Feeding high-moisture corn instead of dry-rolled corn reduces odorous compound production in manure of finishing beef cattle without decreasing performance. J. Anim. Sci. 84, 1767 (Abstr)

AOAC, 1997. Association of Official Analytical Chemists, Official Methods of Analysis. $16^{\text {th }}$ Edition. Arlington, VA 
Beharka A.A., NagarBeharka A.A., Nagaraja T.G., Morrill J.L., Kennedy G.A., Klemm R.D., 1998. Effects of form of the diet on anatomical, microbial, and fermentative development of the rumen of neonatal calves. J. Dairy Sci. 81, 1946-1955

Evans E.W., Pearce G.R., Burnett J., Pilinger S.L., 1973. changes in some physical characteristics of the digesta in the reticulo-rumen of cows fed once daily. Brit. J. Nutr. 20, 357-376

Faisant N., Champ M., Buléon A., Colonna P., Molis C., Lartigue S., Galmiche J.P., Champ M., 1995. Digestion of raw banana starch in the small intestine of healthy humans: structural features of resistant starch. Brit. J. Nutr. 73, 111-123

Hall M.B., Larson C.C., 2004. Ruminal protein metabolites and fibre fermentation differ among nonfibre carbohydrate and protein sources. J. Anim. Feed Sci. 13, Suppl. 1, 83-86

Huntington G.B., 1997. Starch utilization by ruminants: From basic to the bunk. J. Anim. Sci. 75, $852-867$

INRA-tion 3.3. 2006

IZ-INRA, 2001. Standards for Cattle, Sheep and Goat Nutrition (in Polish). National Research Institute of Animal Production, Kraków

Khan M.A., Lee H.J., Lee W.S., Kim H.S., Kim S.B., Ki K.S., Park S.B., Ha J.K., Choi Y.J., 2007. Starch source evaluation in calf starter: I. Feed consumption, body weight gain, structural growth and blood metabolites in Holstein calves. J. Dairy Sci. 90, 5259-5268

Khan M.A., Lee H.J., Lee W.S., Kim H.S., Kim S.B., Park S.B., Baek K.S., Ha J.K., Choi Y.J., 2008. Starch source evaluation in calf starter: II. Ruminal parameters, rumen development, nutrient digestibilities, and nitrogen utilization in Holstein calves. J. Dairy Sci. 91, 1140-1149

Knowlton K.F., Glenn B.P., Erdman R.A., Wilkerson V.A., 2000. The high moisture corn advantage: Greater than we thought. Hoards Dairyman October 25, pp. 728-733

Lane M.A., Baldwin R.L. IV, Jesse B.W., 2000. Sheep rumen metabolic development in response to age and dietary treatment. J. Anim. Sci. 78, 1990-1996

Lane M.A., Baldwin R.L. IV, Jesse B.W., 2002. Developmental changes in ketogenic enzyme gene expression during sheep rumen development. J. Anim. Sci. 80, 1538-1544

Lesmeister K.E., Heinrichs A.J., 2004. Effects of corn processing on growth characteristics, rumen development and rumen parameters in neonatal dairy calves. J. Dairy Sci. 87, 3439-3450

Lesmeister K.E., Tozer P.R., Heinrichs A.J., 2004. Development and analysis of rumen tissue sampling procedure. J. Dairy Sci. 87, 1336-1344

Michalet-Doreau B., Vérité R., Chapoutot P., 1987. Methodologie de la dégradabilité des aliments dans le rumen. Bull. Tech. CRZV Theix, INRA, 69, 5-7

Nocek J.E., Tamminga S., 1991. Site of digestion of starch in the gastrointestinal tract of dairy cows and its effect on milk yield composition. J. Dairy Sci. 74, 3598-3629

Peyraud J.L., Genes-Rulquin C., Vérité R., 1988. Mesure de la digestion de l'azoté des aliments dans l'intestin des ruminant par la technique des sachest mobiles. 1. Evaluation de la quantité de matierés azotées indigestibles en des primipaux aliments. Reprod. Nutr. Develop. 28, 129-130

Quigley J.D., 3 ${ }^{\text {rd }}$, Bernard J.K., 1992. Effects of nutrient source and time of feeding on changes in blood metabolites in young calves. J. Anim. Sci. 70, 1543-1549

Quigley J.D., 3 ${ }^{\text {rd }}$, Caldwell L.A., Sinks G.D., Heitmann R.N., 1991. Changes in blood glucose, nonesterified fatty acids and ketones in response to weaning and feed intake in young calves. J. Dairy Sci. 74, 250-257

SAS, 2001. Release 2.6 for Windows. SAS Institute Inc., Cary, NC

Suarez B.J., Van Reenen C.G., Beldman G., Van Delen J., Dijkstra J., Gerrits W.J.J, 2006a. Effects of supplementing concentrates differing in carbohydrate composition in veal calf diets: I. Animal performance and rumen fermentation characteristics. J. Dairy Sci. 89, 4365-4375 
Suarez B.J., Van Reenen C.G., Gerrits W.J.J., Stockhofe N., Van Vuuren A.M., Dijkstra J., 2006b. Effects of supplementing concentrates differing in carbohydrate composition in veal calf diets: II. Rumen development. J. Dairy Sci. 89, 4376-4386

Zhang Y.Q., Deng X.Z., Zhou Z.M., Ren L.P., Men Q.X., 2007. The effect of inclusion of different processed maize grains and soybeans in the starter diets on rumen fermentation and development characteristics in Holstein bull calves. J. Anim. Feed Sci. 16, Suppl. 2, 525-530 